\title{
List of Captions for Black and White Plates
}

1 Cairo, funerary madrasa and khanqab of Barsbay, 835/ 1432

2 Sivas, Çifte Minare madrasa, stonework detail

3 Divriği, Friday mosque, dome

4 Samarqand, Shah-i Zinda, mausoleum dated 758/1360

5 Cairo, mausoleum of Toghay, inscription on drum

6 Dauran, Friday Mosque, zone of transition

7 Samarqand, Shah-i Zinda, mausoleum of Shad-i Mulk

8 Samarqand, Shah-i Zinda, anonymous mausoleum I, known as that of Ustad 'Alim. Detail of portal façade

9 Divriği, mosque and hospital, façade

10 Ardistan, Friday Mosquae, zone of transition

11 Incir Han, covered hall

$12 \mathrm{Ta}{ }^{c} i z z$, Muzaffariya mosque, qibla façade

13 Bidakhavid, shrine of Shaikh 'Ali Binyaman, alabaster mibrab

14 Yazd, Friday Mosque, dome

15 Jerusalem, Aqsa mosque, façade

16 Jerusalem, Ashrafiya madrasa, upper floor

17 Aleppo, Great Mosque, courtyard with ablutions fountain

18 Aleppo, Great Mosque, central aisle from the west

19 Ramla, White Mosque, minaret

20 Marrakesh, Qubbat al-Barudiyin, mosque fountain, interior

21 Marrakesh, Qubbat al-Barudiyin, mosque fountain, exterior

22 Baghdad, Mirjaniya madrasa, waqfiya

23 Susa, Great Mosque, original sanctuary

24 Damghan, Tari Khana mosque, mibrab and minbar

25 Hama, Great Mosque, minbar of Nur al-Din

26 Jerusalem, Aqsa mosque, minbar, entrance

27 Jerusalem, Aqsa mosquae, minbar, east side

28 Abyana, Friday Mosque, minbar

29 Qairawan, Great Mosque, interior of dome over mib$r a b$

$30 \mathrm{Kufa}$, Great Mosque, portal

31 Mosul, Nuri mosque, mibrab façade

32 Jerusalem, Aqsa mosque, main arch with Fatimid mosaics

33 Cairo, mosque of Baibars, maqsura

34 Qairawan, Great Mosque, minbar and maqsura

35 Damascus, Great Mosque, aerial view

36 Hama, Great Mosque, bait al-mal

$37 \mathrm{Ma}^{\mathrm{c}}$ arrat al-Nu'man, Great Mosque, courtyard, fountain and minaret

38 Qairawan, Great Mosque, mibrab area with minbar, magsura, dome and polycandelon

39 Muhammadiya, Masjid-i Sar-i Kucha

40 Aksaray, Ulu Cami, interior

$41 \mathrm{Ta}^{\mathrm{c}} \mathrm{izz}$, Ashrafiya mosque, dome

42 Damascus, Great Mosque, interior before the fire of 1893
43 Samarra, Great Mosque, outer wall

44 Cordoba, Great Mosque, sanctuary showing Christian chapel

45 Toledo, mosque at Bar Mardum, façade

46 Mahdiya, Great Mosque, façade

47 Cordoba, Great Mosque, interior

48 Tunis, Zaituna mosque, interior

49 Cordoba, Great Mosque, exterior façade

50 Cordoba, Great Mosque, window

51 Qairawan, Mosque of Muhammad b. Khairun, façade

$52 \mathrm{Fez}$, Qarawiyin mosque, façade of sanctuary

53 Marrakesh, Kutubiya mosque, general view

54 Marrakesh, Kutubiya mosque, lateral façade

55 Cordoba, Great Mosque, Capilla de Vilaviciosa, interlacing arches

56 Seville, Great Mosque, façade of sanctuary

57 San'a', Great Mosque, courtyard

58 Asnaf, Masjid al-'Abbas. interior

59 Ibb, Great Mosque, courtyard

60 Dhu Ashraq, mosque, courtyard

61 Asnaf, Masjid al-'Abbas, ceiling

62 Diyarbakr, Great Mosque, sanctuary façade

63 Konya, 'Ala' al-Din mosque, main façade

64 Beyșehir, Eșrefoghlu Süleyman Bey Cami, interior

65 Divriği, mosque and hospital, interior of hospital

66 Divriği, mosque and hospital, exterior sculpture

67 Divriği, mosque and hospital, south-west portal

68 Konya, Sahib 'Ata' mosque, portal

69 Cairo, Mosque of al-Mu'ayyad, vault in portal

70 Abyana, Friday Mosque, ceiling

71 Sujas, Friday Mosque, dome chamber

72 Ardistan, Friday Mosque, bays leading to dome chamber

73 Herat, Friday Mosque, iwan

74 Ashtarjan, Friday Mosque, courtyard façade looking north-east

75 Ashtarjan, Friday Mosque, mibrab and zone of transition

76 Varamin, Friday Mosque, courtyard arcade

77 Samarqand, Bibi Khanum mosque, sanctuary iwan

78 Samarqand, Bibi Khanum mosque, corner minaret

79 Bukhara, Masjid-i Kalan, arcade

80 Samarqand, Bibi Khanum mosque, lateral dome chamber

81 Anau, mosque, east side

82 Anau, mosque, sanctuary iwan

83 Istanbul, Selimiye mosque, arcade

84 Istanbul, Sultan Bayazid mosque, pier

85 Istanbul, Sehzade mosque, interior

86 Istanbul, Mihrimah mosque, general view

87 Istanbul, Süleymaniye complex, model

88 Cairo, Aqmar mosque, façade

89 Tlemcen, Sidi al-Halwi mosque, courtyard 


\section{ISLAMIC ARCHITECTURE}

90 Yazd, Friday Mosque, interior of dome chamber

91 Uzgend, minaret

92 Aleppo, Great Mosque, minaret

93 Qairawan, Great Mosque, minaret

94 Marrakesh, Kutubiya mosque, upper part of minaret

95 Rabat, Mosque of Hassan, minaret

96 Seville, Great Mosque, Giralda minaret

97 Mujda, minaret

98 Samarra, Great Mosque and minaret

99 Samarra, Mosque of Abu Dulaf, minaret

100 Cairo, Mosque of Ibn Tulun, minaret

101 Hama, Great Mosque, minaret

102 Miskina, minaret

103 Bukhara, Masjid-i Kalyan, minaret, upper part

104 Vabkent, minaret

105 Bukhara, Masjid-i Kalyan, minaret, lower part

$106 \mathrm{Ta}^{3} u q / \mathrm{Daquq}$, minaret

107 Irbil, minaret

108 Isfahan, Saraban minaret

109 Isfahan, Chihil Dukhtaran minaret

110 Zavara, Masjid-i Pa Minar, minaret

111 Ghazna, minaret of Mas'ud III

112 Jam, minaret

$113 \mathrm{Jam}$, minaret, upper section

114 Sivas, Great Mosque, minaret

115 Mardin, Great Mosque, minaret

116 Antalya, Yivli mosque, minaret

117 Luxor, Mosque of Abu'l-Haji, minaret

118 Cairo, Mosque of al-Hakim, northern salient and minaret, from the west

119 Cairo, minaret of Bashtak

120 Cairo, Ghanim al-Bahlawan mosque, minaret

121 Cairo, Mughalbay Taz mosque, base of minaret

122 Cairo, Mughalbay Taz mosque, minaret

123 Baghdad, Mirjaniya madrasa, sanctuary façade

124 Samarqand, Rigistan, madrasa of Ulugh Beg, side view

125 Samarqand, Rigistan, Shir Dar madrasa, roof

126 Isfahan, Madrasa-yi Imami, courtyard

127 Bukhara, madrasa of 'Abd al-'Aziz Khan, courtyard

128 Tabas, Madrasa-yi Du Dar, courtyard

129 Zuzan, madrasa, north iwan

130 Zuzan, madrasa, south iwan, general view

131 Zuzan, madrasa, south iwan, detail

132 Zuzan, madrasa, dating inscription

133 Baghdad, Mirjaniya madrasa, entrance to upper-floor room

134 Baghdad, so-called " "Abbasid palace": vault

135 Aleppo, al-Firdaus, jami and madrasa

136 Aleppo, Sharifiya madrasa

137 Cairo, madrasa of Qa'it Bay at al'at al-Kabsh

$138 \mathrm{Rada}^{c}$, Madrasa al-'Amiriya

$139 \mathrm{Ta}^{\mathrm{c} i z z}, \mathrm{Mu}^{\mathrm{c}}$ tabiya madrasa, interior

140 Cairo, complex of Sultan Qala'un

141 Cairo, mosque-madrasa of Sultan Hasan, exterior

142 Cairo, mosque-madrasa of Sultan Hasan, student cells

143 Cairo, madrasa of Barsbay, 828/1425

144 Cairo, funerary madrasa of $\mathrm{Q}^{\prime}$ it Bay, general view

145 Cairo, funerary madrasa of $\mathrm{Q}^{3}$ it Bay, north-west iwan

146 Jerusalem, Is'ardiya madrasa

147 Jerusalem, Ashrafiya madrasa, portal

148 Jerusalem, Ashrafiya madrasa, Haram façade

149 Konya, Qaratai madrasa, interior
150 Konya, Ince Minare madrasa, portal

151 Sivas, Gök madrasa, main façade

152 Sivas, Gök madrasa, detail of portal sculpture

153 Tokat, Gök madrasa, courtyard

154 Amasya, Kapi Aghasi madrasa, general view

155 Baghdad, Mustansiriya madrasa, corridor

156 Baghdad, Mirjaniya madrasa, courtyard looking north

157 Baghdad, Mirjaniya madrasa, prayer hall

158 Yazd, Shamsiya madrasa, inscription

159 Khargird, Madrasa-yi Ghiyathiya: lecture hall, vaulting

160 Turbat-i Jam, shrine complex, courtyard

161 Bukhara, madrasa of 'Abd al-'Aziz Khan, vaulting

162 Samarqand, Rigistan, madrasa of Ulugh Beg, façade

163 Samarqand, Rigistan, madrasa of Ulugh Beg, portal

164 Samarqand, Rigistan, madrasa of Ulugh Beg, corridor

165 Samarqand, Rigistan, Shir Dar madrasa, niche

166 Samarqand, Rigistan, Shir Dar madrasa, courtyard

167 Samarqand, Rigistan, Tila Kari madrasa, side view

168 Bukhara, madrasa of 'Abdallah Khan, portal

169 Bukhara, Mir-i 'Arab madrasa, portal

$170 \mathrm{Fez}$, Madrasa al-'Attarin, carved woodwork

171 Sale, Zawiya al-Nussak, portal

172 Sale, madrasa, of Abu'l-Hasan, covered arcade on south side

173 Marrakesh, Ben Yusuf madrasa, mibrab in oratory

$174 \mathrm{Fez}$, Madrasa al-'Attarin

175 Samarra, Qubbat al-Sulaibiya

176 Samarqand, Shah-i Zinda (in foreground: tomb of Chujuk Bika)

177 Linjan, shrine of Pir-i Bakran, niche with mugarnas hood

178 Bukhara, tomb of Bayan Quli Khan, interior

179 Safid Buland, tomb of Shaikh Fadl

180 Aswan, mausolea

181 Uzgend, tomb dated 582/1186-7, detail of portal

182 Samarqand, Shah-i Zinda, tomb of Shad-i Mulk Aqa, portal

183 Samarqand, Shah-i Zinda, tomb of Ustad 'Alim Nasafi, interior

184 Samarqand, Gur-i Amir

185 Cairo, tomb of Yunus al-Dawadar

186 Marrakesh, tombs of the Sa'dians, interior

187 Rabat, Chilla necropolis

188 Zafar Dhibin, mausoleum within the mosque

189 Abarquh, Gunbad-i 'Ali

190 Samiran, anonymous mausoleum

191 Kharraqan, later tower

192 Merv, mausoleum of Sultan Sanjar

193 Bust, Shahzada Sarbaz

194 Gunbad-i Qabus

195 Kashmar, tomb, vaulting of interior

196 Qumm, tomb of 'Imad al-Din, interior

197 Qumm, tombs in the Bagh-i Sabz

198 Natanz, shrine of 'Abd al-Samad, interior of tomb chamber

199 Bukhara, "Tomb of the Samanids"

200 Bukhara, "Tomb of the Samanids", detail of gallery

201 Bukhara, "Tomb of the Samanids", interior, zone of transition

202 Safid Buland, tomb of Shaikh Fadl, interior

203 Uzgend, tomb of Jalai al-Din Husain 


\section{LIST OF CAPTIONS FOR BLACK AND WHITE PLATES}

204 Uzgend, tomb associated with Nasr b. 'Ali, squinch

205 Bukhara, complex at Fathabad, shrine of Saif al-Din Bakharzi

206 Kirman, Jabal-i Sang

207 Sultaniya, mausoleum of Öljeitü

208 Sultaniya, mausoleum of Öljeitü, tilework in the interior

209 Yazd, tomb of Rukn al-Din, interior

210 Samarqand, Shah-i Zinda, tomb of Qadizada Rumi

211 Samarqand, Shah-i Zinda, tomb of Shad-i Mulk Aqa, interior dome

212 Samarqand, Shah-i Zinda, tomb of Shad-i Mulk Aqa, interior

213 Samarqand, Shah-i Zinda, tomb of Qutham b. 'Abbas, interior, zone of transition

214 Samarqand, Shah-i Zinda, street in the necropolis

215 Samarqand, Gur-i Amir, portal

216 Samarqand, Gur-i Amir, tilework in portal

217 Turkistan, shrine of Khwaja Ahmad Yasavi, portal

218 Turkistan, shrine of Khwaja Ahmad Yasavi, side view

219 Turkistan, shrine of Khwaja Ahmad Yasavi, doors

220 Bukhara area, Char Bakr shrine

221 Mahan, shrine of $\mathrm{Ni}$ 'matallah Wali, vaulting

222 Kalar-i Nadiri, tomb of Nadir Shah

223 Tokat, tomb of Nur al-Din b. Sentimur

224 Kayseri, Döner Kümber

225 Kirsehir, tomb of Melik Ghazi

226 Cairo, Sab'a Banat

227 Aswan, mashbad

228 Cairo, tombs of al-Ja'fari (foreground) and Sayyida 'Atiqa

229 Cairo, aerial view of Mamluk tombs (lower centre: khanqah of Faraj b. Barquq; upper centre: Mosque of Sultan Inal; top right: tomb of Qansub $\mathrm{Abu} \mathrm{Sa}$ id; bottom left: tomb of Jani Bay al-Ashrafi)

230 Cairo, tomb of Toghay

231 Cairo, tomb of Yunus al-Dawadar, interior

232 Cairo, tomb of the 'Abbasid caliphs, niche and window

233 Cairo, tomb of Sultan al-Salih Najm al-Din

234 Damascus, madrasa and mausoleum of 'Izz al-Din

235 Damascus, tomb of Shaikh 'Ali al-Faranthi, zone of transition

236 Aleppo, tomb of Khair Bay (Jami' Shaikh 'Ali Shatila)

237 Damascus, madrasa and mausoleum of Nur al-Din, interior of mugarnas dome

238 Imam Dur, tomb of Muslim b. Quraish

239 Imam Dur, tomb of Muslim b. Quraish, interior

240 Baghdad, tomb known as that of Sitt Zubaida

241 Cairo, funerary complex of Sultan Qala'un, interior of mausoleum

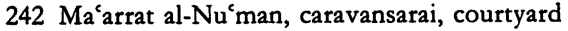

243 Aleppo, Khan Utchan, portal

244 Cairo, wakala of Qa'it Bay at Bab al-Nasr

245 Urfa, Khan Shifta, gateway

246 Ribat-i Malik, portal

247 Ribat-i Sharaf, courtyard

248 Ribat-i Sharaf, interior, detail
249 Ribat-i Sipanj, main façade

250 Sultan Han near Kayseri, courtyard with mosque

251 Sultan Han near Kayseri, main façade

252 Qaratai Han, portal

253 Cairo, Khah al-Khalili, vaulting

254 Damascus, Süleyman Pasha khan, interior

255 Damascus, As'ad Pasha khan, interior

256 Fez, Funduq, al-Titwaniyin, courtyard

257 Cairo, wakala, sabil and sabil kuttab of $\mathrm{Qa}^{\text {cit }}$ Bay near al-Azhar

258 Cairo, wakala complex of Qa it Bay near al-Azhar

259 Aleppo, Khan al-Sabun, courtyard

260 Aleppo, Khan al-Wazir, gateway

261 Aleppo, Khan al-Sabun, window over entrance

262 Baghdad, Khan Mirjan, corbels for interior gallery

263 Baghdad, Khan Mirjan, main façade

264 Baghdad, Khan Mirjan, interior

265 Baghdad, Khan Mirjan, general view

266 Sin, caravansarai, lateral façade

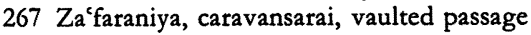

268 Sangbast, caravansarai

269 Bisutun, caravansarai, entrance complex from courtyard

270 Gaz, caravansarai, courtyard

271 Incir $\mathrm{Han}$, general view

272 Shahr-i Sabz, Aq Saray, main portal, detail

273 Shahr-i Sabz, Aq Saray, main portal, upper part

274 Mshatta, façade, detail

275 Mshatta, royal quarters

276 Ctesipon, palace

277 Ukhaidir, aerial view

278 Ukhaidir, east façade

279 Ukhaidir, vault

280 Samarra, stucco, Style 1

281 Samarra, stucco, Style 2

282 Samarra, stucco, Style 3

283 Samarra, Jausaq al-Khaqani, Bab al-'Amma

284 Samarra, Qasr al-'Ashiq

285 Lashkar-i Bazar area, arch at Bust

286 Mosul, Qara Saray

287 Sinjar, niche

288 Shahr-i Sabz, Aq Saray, main portal

289 Shahr-i Sabz, Aq Saray, main portal, rear view

290 Shahr-i Sabz, Aq Saray, main portal, detail

$291 \mathrm{Na}^{2}$ in, palace, vaulting

292 Isfahan, Hasht Bihisht, entrance façade

293 Isfahan, Chihil Sutun, fresco of a royal audience

294 Cairo, palace of Yashbak, vaulting

295 Cairo, Sikkat al-Mardani or house of Qa'it Bay

296 Jerusalem, palace of Sitt Tunshuq

297 Madinat al-Zahra, Dar al-Mulk, audience hall

298 Granada, Alhambra, Court of the Lions

299 Granada, Alhambra, Court of the Lions, north façade

300 Granada, Alhambra, Hall of the Abencerrajes, mugarnas

301 Granada, Generalife, garden

302 Istanbul, Topkapi Saray, Baghdad Kiosk 